\title{
Socio-economic aspects and impact of land use change on sediment production dynamics in the northeastern region of India
}

\author{
U.C. SHARMA ${ }^{1}$, VIKAS SHARMA ${ }^{2}$ \\ ${ }^{1}$ Centre for Natural Resources Management, India \\ ${ }^{2}$ S.K. University of Agricultural Sciences \& Technology, India
}

\begin{abstract}
Socio-economic aspects and impact of land use change on sediment dynamics in the northeastern region of India. The northeastern region of India, with an area of $255090 \mathrm{~km}^{2}$, is predominantly hilly. Major socio-economic factors affecting sediment production in the region are; shifting cultivation, land tenure system, fast growing population, small land-holdings, deforestation and free range grazing. A multi-disciplinary long-term study showed that 92.9 to $99.1 \%$ of rainwater can be retained in-situ, compared to $66.3 \%$ in shifting cultivation. Mean annual soil loss varied from 11.2 to $97.2 \mathrm{t} \mathrm{km}^{-2}$ in new land use systems as against $3621.3 \mathrm{t} \mathrm{km}^{-2}$ in shifting cultivation. The sediment load per litre of runoff from watersheds varied from 1250-20,300 mg suspended sediment, 5.4 to $23.6 \mathrm{mg} \mathrm{NO}-\mathrm{N}, 2.3$ to $6.5 \mathrm{mg}$ $\mathrm{P}-\mathrm{PO}_{4}, 17.2$ to $35.8 \mathrm{mg} \mathrm{K}_{2} \mathrm{O}, 0.4$ to $1.8 \mathrm{mg} \mathrm{Zn}, 0.9$ to $2.7 \mathrm{mg} \mathrm{Mn}, 6.5$ to $12.0 \mathrm{mg} \mathrm{Mg}, 7.1$ to $18.4 \mathrm{mg}$ $\mathrm{Fe}$ and 4.0 to $7.2 \mathrm{mg} \mathrm{SO}_{4}$. The sediment transport from the catchments showed spatial and temporal variations.
\end{abstract}

Key words: socio-economic aspects, land use change, sediment production, shifting cultivation.

\section{INTRODUCTION}

Though endowed with abundant natural resources, the north-eastern region of India has remained economically backward due to their indiscriminate use and mismanagement. Socio-economic constraints viz. shifting cultivation, land tenure system, small size of land holdings, unabated deforestation, free range grazing and undulating terrain have affected the sediment yield and, quantity and quality of available water (Sharma 1998, 2003). Shifting cultivation is an uneconomical socio-economic issue and the farmers are socio-culturally attached with the practice, because most of the festivals and rituals are associated with it. In most of the states of the region, the farmers have only usufructuary rights over land as the land belongs either to village chief or community. The fast growing population has pressurized the food production base and to satisfy their needs, the people have misused the natural resources (Sharma 2003).

The region receives about $510 \mathrm{~km}^{3}$ of rain water, annually at an annual average of $2450 \mathrm{~mm}$. Judicious management of water resources will not only reduce the heavy loss of soil and nutrients but also reduce the flood events in the region. Shifting cultivation is practised in $3869 \mathrm{~km}^{2}$ area, annually in north eastern region of India; however the total affected area is $14660 \mathrm{~km}^{2}$. It has resulted in huge soil erosion in the hills and silting of river beds and floods in the plains. 
Land clearance, land use change and other facets of catchment disturbance, soil conservation and sediment control programmes and dam construction are shown to have resulted in significant recent changes in the sediment loads of many world rivers (Walling 2000, 2008). Deforestation in shifting cultivation has depleted the biodiversity of the region. The important issue is to promote the conservation and sustainable use of natural resources which allow long term economic growth and enhancement of productive capacity, along with being equitable and environmentally acceptable (El Bassam 1997).

The region, though having sufficient water in aggregate, cannot boast of adequate quantities of water at all the places and during all the times. The region receives about $510 \mathrm{~km}^{3}$ of water as rainfall, at an annual average of $2474 \mathrm{~mm}$. However, gross misuse and mismanagement of rainwater has resulted in soil erosion, land and environment degradation in the hills and silting of river beds and frequent floods in the plains (Sharma 1998). The problem has been aggravated by the prevalence of shifting cultivation in $3869 \mathrm{~km}^{2}$, annually. There is annual loss of 83.3 million tones of soil and $10.65,0.37$ and 6.05 thousand tones of available $\mathrm{N}, \mathrm{P}_{2} \mathrm{O}_{5}$ and $\mathrm{K}_{2} \mathrm{O}$, respectively due to shifting cultivation alone (Sharma and Prasad 1995). The major problems of facing the harmonious development and management of water resources system in the region are socio-economic constraints, paucity of reliable data and lack of human and institutional capacity necessary for confronting the complex interactions of the hydrological cycle with societal needs, socio-economic constraints and the environment. A long-term-multidisciplinary study was, therefore, undertaken to assess the soil and nutrient losses from the hill slopes, insitu retention of rainwater as affected by vegetation and, water and soil conservation measures to reduce runoff as well as its impact on the environment.

\section{MATERIAL AND METHODS}

The northeastern region of India (Fig. 1), comprising seven states viz. Arunachal Pradesh, Assam, Manipur, Meghalaya, Mizoram, Nagaland Tripura, is predominantly hilly. Due to anthropogenic and natural factors, the region is subjected to heavy soil erosion and sediment deposits in the river channels, causing floods. To study the socio-economic aspects, old records were scanned as well as benchmark survey was conducted in selected areas. For the impact of land use on sediment yield, a long-term multidisciplinary study was undertaken with seven and land use systems to monitor their comparative efficacy with regard to in-situ retention of rain water, water yield, surface and subsurface flows and sediment yield from different watersheds as well as to evolve eco-friendly, viable and sustainable land use systems to replace shifting cultivation. The watersheds have slopes varying from $32 \%$ to $53 \%$, at an altitudes varying from $920 \mathrm{~m}$ to $980 \mathrm{~m}$ above mean sea level. The soil conservation measures followed were bench terracing, contour bunds, half-moon terraces, trenching and grassed water-ways. The scientists from the disciplines of soil and water conservation, soil science, plant protection and social sciences are engaged in the project to study their relevant fields. The soil and 


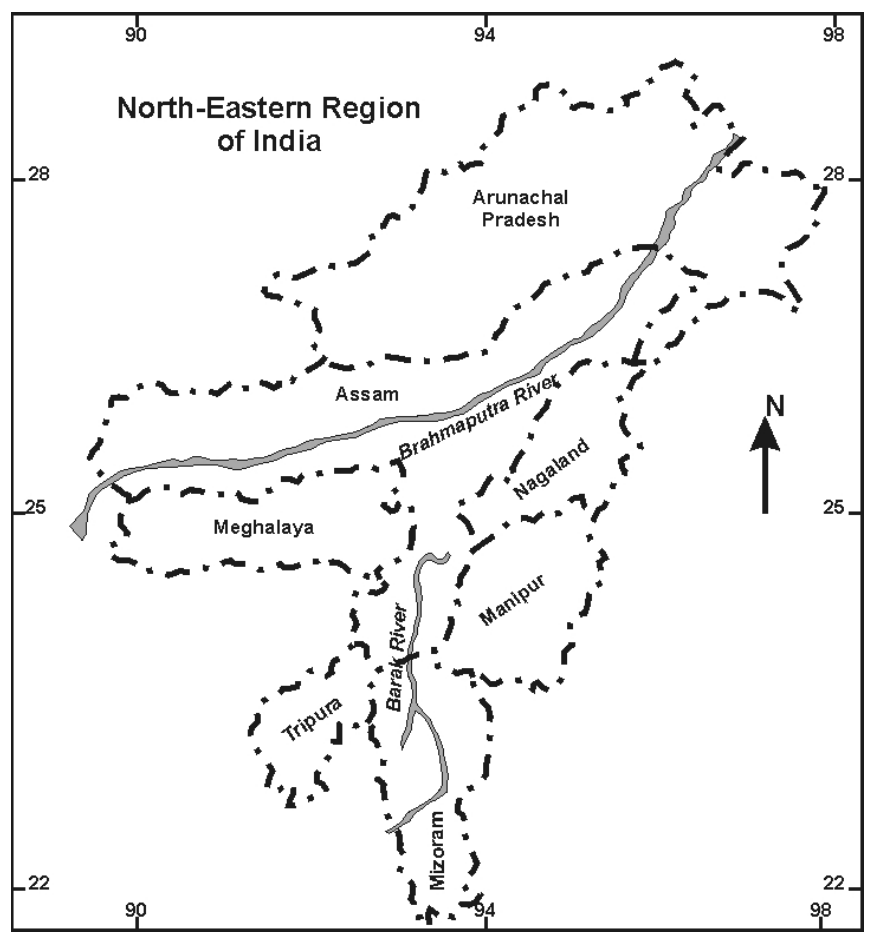

FIGURE 1. Northeastern region of India

TABLE 1. Vegetation cover in different land use systems

\begin{tabular}{|l|c|l|l|l|}
\hline Land use & $\begin{array}{c}\text { Slope } \\
{[\%]}\end{array}$ & Crops/trees & Livestock & $\begin{array}{l}\text { Soil and water } \\
\text { conservation measure }\end{array}$ \\
\hline $\begin{array}{l}\text { Livestock } \\
\text { (grasses and } \\
\text { fodders) }\end{array}$ & 32.0 & $\begin{array}{l}\text { Maize, rice-bean, oats, pea, guinea } \\
\text { grass, tapioca, broom grass }\end{array}$ & $\begin{array}{l}\text { Cows, pigs, } \\
\text { rabbits }\end{array}$ & $\begin{array}{l}\text { Contour bunds, grassed } \\
\text { water-ways, trenches }\end{array}$ \\
\hline Forestry & 38.0 & $\begin{array}{l}\text { Alder nepalensis, Albziia lebbeck, } \\
\text { Acacia auriculiformis }\end{array}$ & None & None \\
\hline Agro-forestry & 32.2 & $\begin{array}{l}\text { Ficus hookerii, Eucalyptus, guava, } \\
\text { pine, pineapple, french bean, pulse } \\
\text { crops }\end{array}$ & $\begin{array}{l}\text { Goats, } \\
\text { rabbits }\end{array}$ & Contour bunds \\
\hline Agriculture & 32.4 & $\begin{array}{l}\text { Beans, radish, maize, paddy, ginger, } \\
\text { turmeric, ground-nut, oats, grasses } \\
\text { on risers }\end{array}$ & Cows & $\begin{array}{l}\text { Bench terraces, contour } \\
\text { bunds, grassed water- } \\
\text { ways }\end{array}$ \\
\hline $\begin{array}{l}\text { Agri-horti- } \\
\text {-silvi-pastoral }\end{array}$ & 41.8 & $\begin{array}{l}\text { Beans, vegetables, guava, citrus, gin- } \\
\text { ger, Alder nepalensis, Ficus hookeri, } \\
\text { grasses }\end{array}$ & Pigs, goats & $\begin{array}{l}\text { Bench terraces, contour } \\
\text { bunds, grassed water- } \\
\text { ways }\end{array}$ \\
\hline Horticulture & 53.2 & $\begin{array}{l}\text { Peach, pear, citrus, guava, lemon, } \\
\text { vegetables }\end{array}$ & None & Same as above \\
\hline
\end{tabular}


nutrient losses were monitored through monitoring gauges fixed at the exit point of each watershed. The meteorological data were collected in the observatory located near the project site. The crops grown in different land use systems, soil conservation measures followed and animals kept as per farmer's requirement are given in Table 1. The chemical analysis of soil and water samples was done as per procedures outlined by Jackson (1973).

\section{RESULTS AND DISCUSSION}

\section{Socio-economic aspects}

The homo-sapiens were under awe of natural objects such as mountain, oceans, rivers, forests etc., from the pre-historic age. The people were small in number, primitive in technology and their needs were extremely limited. Slowly, their number increased and needs multiplied. The northeastern region is inhabited by various tribes and their economy can conveniently be divided into hunting, nomadism, pastrolism, shifting cultivation and now, settled cultivation up to some extent. The rural economy of the region is mainly dependent on shifting cultivation. In the past, when the land was in abundance and population sparse, the rotational cycle of shifting cultivation in the region used to be 25 to 30 years, the land getting enough time for rejuvenation of vegetation. The soil fertility was maintained with in-situ burning of vegetation of forests and the production was enough to feed the limited population. However, with increase in population, the rotational cycle has come down to 2 to 10 years and the land does not get enough time for rejuvenation. The sediment yield from shifting cultivation areas has increased tremendously (Tab. 2). The annual area under shifting cultivation in the region is $3869 \mathrm{~km}^{2}$, whereas total area affected is $14660 \mathrm{~km}^{2}$ and about 443.3 thousand families are involved in the practice (Anonymous 2000). Shifting cultivation is not only a set of agricultural practices but implies the whole nexus of people's religious beliefs, attitudes, self image and tribal identity. This kind of inter-connections between different elements and domains of social life restricts the cultivators to leave shifting cultivation. As high as 70.6 and $130.2 \mathrm{t} \mathrm{ha}^{-1}$ of annual soil loss has been reported during first and second year of shifting cultivation on a hill having a slope of $70 \%$ (Singh and Singh 1978). Annual soil loss from the region is 88.3 million tonnes from shifting cultivation land, 90.7 million tonnes from other agricultural land and 422.7 million tonnes from non-agricultural land. It was estimated that annual loss of $\mathrm{N}, \mathrm{P}$, $\mathrm{K}, \mathrm{Mn}, \mathrm{Zn}, \mathrm{Ca}$ and $\mathrm{Mg}$ is $686.0,100.2$, $511.0,22.7,14.0,57.3$ and 43.4 thousand tonnes, respectively (Sharma and Sharma, 2004). The soil fertility is on decline as there is limited material to burn and add to the soil (Tab. 3). The results showed that at least 20 years time is necessary for rejuvenation of enough vegetation to get optimum available major nutrients for crop support. In 20 years cycle, the available $\mathrm{N}, \mathrm{P}_{2} \mathrm{O}_{5}$ and $\mathrm{K}_{2} \mathrm{O}$ increased by $55.1 \%, 22.8 \%$ and $128.4 \%$, respectively over their initial status. The low increase in available $\mathrm{P}_{2} \mathrm{O}_{5}$ compared to other nutrients was due to the reason that soil was strongly acidic in reaction, most of the phosphorus got fixed as aluminium and iron compounds. 
TABLE 2. Shifting cultivation and soil and nutrient loss in the region

\begin{tabular}{|l|c|c|c|c|c|r|r|}
\hline \multirow{2}{*}{ State } & \multicolumn{3}{|c|}{ Shifting cultivation } & \multicolumn{2}{c|}{$\begin{array}{c}\text { Total soil } \\
\text { loss } \\
{[\text { million }} \\
\text { tonnes] }\end{array}$} & \multicolumn{3}{|c|}{$\begin{array}{c}\text { Nutrient loss } \\
{[000 \text { ' }]}\end{array}$} \\
\cline { 2 - 3 } & $\begin{array}{c}\text { Annual area } \\
{\left[\mathrm{km}^{2}\right]}\end{array}$ & $\begin{array}{c}\text { Fallow period } \\
\text { [years] }\end{array}$ & $\begin{array}{c}\text { Soil loss } \\
\text { [million tonnes] }\end{array}$ & $\mathrm{N}$ & $\mathrm{P}$ & $\mathrm{K}$ \\
\hline $\begin{array}{l}\text { Arunachal } \\
\text { pradesh }\end{array}$ & 700 & $3-10$ & 14.5 & 178.1 & 217 & 36.6 & 153 \\
\hline Assam & 696 & $2-10$ & 12.3 & 178.4 & 201 & 33.4 & 155 \\
Manipur & 900 & $4-7$ & 20.4 & 64.0 & 76 & 7.4 & 63 \\
\hline Meghalaya & 530 & $5-7$ & 14.2 & 57.7 & 62 & 7.0 & 48 \\
\hline Mizoram & 630 & $3-4$ & 13.0 & 39.4 & 60 & 6.9 & 40 \\
Nagaland & 190 & $5-8$ & 8.0 & 41.7 & 44 & 5.2 & 34 \\
Tripura & 223 & $4-9$ & 5.9 & 15.4 & 26 & 2.7 & 18 \\
\hline Total & 3869 & $2-10$ & 88.3 & 601.2 & 686 & 99.2 & 511 \\
\hline
\end{tabular}

TABLE 3. Available soil nutrients per ha by burning of rejuvenated vegetation

\begin{tabular}{|l|c|c|c|c|c|c|}
\hline \multirow{2}{*}{$\begin{array}{l}\text { Available nutrients } \\
{\left[\mathrm{kg} \cdot \mathrm{ha}^{-1}\right]}\end{array}$} & \multicolumn{6}{|c|}{ Period after abandoning shifting cultivation [years] } \\
\cline { 2 - 7 } & Initial & 5 & 10 & 15 & 20 & 25 \\
\hline $\mathrm{N}$ & 176 & 182 & 204 & 244 & 273 & 275 \\
\hline $\mathrm{P}_{2} \mathrm{O}_{5}$ & 5.7 & 5.9 & 6.2 & 6.9 & 7.0 & 7.2 \\
\hline $\mathrm{K}_{2} \mathrm{O}$ & 123 & 130 & 162 & 248 & 281 & 276 \\
\hline
\end{tabular}

More than $65 \%$ of the workers in the region are engaged in agriculture or allied sectors and the rest are marginal or non-workers (Tab. 4). The land tenure system in the north-eastern region is unique. The land belongs either to (1) village chief, (2) community or (3) individuals. In the first two categories, the farmers have usufructuary rights over land and therefore have little interest in its development and protection from soil erosion. The prevalence of free range grazing by animals during winter season (December to February) by community order, discourages the cultivators from going for winter crops. Free range grazing is responsible for huge sediment yield from hill slopes as well as valley lands. Fast urbanization and change in life style of the people has also affected natu- ral resources management. With proper vegetative cover, maximum rainwater could be retained in-situ and the soil can retain sufficient moisture for growing winter crops (Sharma 2001). This would also help to reduce runoff and soil loss and consequently better ecological conditions could be assured. Fast increase in population (Tab. 5) and in an effort to enhance crop productivity to sustain this has put extreme pressure on land resources, resulting in heavy sediment loads in run-off and choking of fluvial system. Virtually all developing countries, even those with adequate water in the aggregate, suffer from debilitating regional and seasonal shortages (IFPRI 1995). Since food productivity is highly dependent on the spatial and seasonal changes in water availability, 
TABLE 4. Economic classification of population in northeastern region [per cent]

\begin{tabular}{|l|c|c|c|c|}
\hline State & Cultivators & $\begin{array}{c}\text { Agricultural } \\
\text { labourers }\end{array}$ & $\begin{array}{c}\text { Household industry, } \\
\text { processing, etc. }\end{array}$ & $\begin{array}{c}\text { Marginal workers/ } \\
\text { /non-workers }\end{array}$ \\
\hline Arunachal pradesh & 60.4 & 5.1 & 0.2 & 34.3 \\
\hline Assam & 50.9 & 12.1 & 0.9 & 36.1 \\
\hline Manipur & 61.8 & 6.7 & 5.8 & 25.7 \\
\hline Meghalaya & 55.3 & 12.5 & 0.4 & 31.8 \\
\hline Mizoram & 61.3 & 3.3 & 1.0 & 34.4 \\
\hline Nagaland & 72.6 & 1.4 & 0.4 & 25.6 \\
\hline Tripura & 38.1 & 23.9 & 1.4 & 36.6 \\
\hline
\end{tabular}

TABLE 5. Population and food grains situation in the northeastern region of India

\begin{tabular}{|c|c|c|c|c|}
\hline \multirow{2}{*}{ Year } & \multirow{2}{*}{$\begin{array}{c}\text { Population } \\
\text { [millions] }\end{array}$} & \multicolumn{3}{|c|}{ Foodgrains [million tonnes] } \\
\hline & & production & requirement & deficit \\
\hline 1951 & 10.5 & 2.10 & 1.79 & 0.31 \\
\hline 1961 & 14.5 & 2.90 & 2.08 & 0.82 \\
\hline 1971 & 19.6 & 3.92 & 3.01 & 0.91 \\
\hline 1981 & 24.7 & 4.94 & 3.84 & 1.10 \\
\hline 1991 & 31.5 & 6.30 & 4.93 & 1.37 \\
\hline 2001 & 40.2 & 8.04 & 5.96 & 2.08 \\
\hline 2021 & 60.9 & 12.18 & 9.02 & 3.16 \\
\hline
\end{tabular}

the food security cannot be ensured for all times unless suitable measures are undertaken to minimize the effect of runoff on soil erosion. The region has a food grains deficit of about 2.5 million tonnes and the deficit gap is widening year after year (Sharma 1999).

The sediment load per litre of runoff from watersheds varied from 1250 $-20300 \mathrm{mg}$ soil, 5.4 to $23.6 \mathrm{mg} \mathrm{NO}$ - $\mathrm{N}, 2.3$ to $6.5 \mathrm{mg} \mathrm{P}-\mathrm{PO}_{4}, 17.2$ to 35.8 $\mathrm{mg} \mathrm{K} \mathrm{K}_{2} \mathrm{O}, 0.4$ to $1.8 \mathrm{mg} \mathrm{Zn}, 0.9$ to $2.7 \mathrm{mg}$ $\mathrm{Mn}, 6.5$ to $12.0 \mathrm{mg} \mathrm{Mg}, 7.1$ to $18.4 \mathrm{mg}$ $\mathrm{Fe}$ and 4.0 to $7.2 \mathrm{mg} \mathrm{SO}_{4}$. The sediment transport from the catchments showed spatial and temporal variations. Intensification of agriculture has potentially harmful impact on already fragile hydrological system.

\section{Effect of land use and rainfall on soil loss}

The average sediment yield was only $0.44 \%, 2.68 \%, 1.47 \%, 0.31 \%, 0.73 \%$ and $2.27 \%$ in fodder, forestry, agro-forestry, agriculture, agri-horti-silvi-pastoral and horticulture land use systems of that of shifting cultivation (Tab. 6). The average sediment yield varied between $11.2 \mathrm{t} \mathrm{km}^{-2}$ in agriculture land use and $3621.3 \mathrm{t} \mathrm{km}^{-2}$ in the shifting cultivation. Highest average sediment yield in new land use systems was $71.7 \mathrm{t} \mathrm{km}^{-2}$ when the annual rainfall was $2770 \mathrm{~mm}$ and minimum $28.1 \mathrm{t} \mathrm{km}^{-2}$ when the annual rainfall was $1992 \mathrm{~mm}$ as against $4499.7 \mathrm{~km}^{-2}$ and $2669.4 \mathrm{~km}^{-2}$ in shifting cultivation, respectively. More than $90 \%$ of rainwater was retained in- 
TABLE 6. Effect of land use and precipitation on the sediment yield through runoff $\left[\mathrm{t} \mathrm{km}^{-2}\right]$

\begin{tabular}{|l|r|r|r|r|r|r|r|}
\hline \multirow{2}{*}{ Land use } & \multicolumn{7}{|c|}{ Annual rainfall [mm] } \\
\cline { 2 - 8 } & \multicolumn{1}{|c|}{2195} & \multicolumn{1}{|c|}{2705} & \multicolumn{1}{|c|}{2770} & \multicolumn{1}{c|}{2599} & \multicolumn{1}{c|}{2388} & \multicolumn{1}{c|}{1992} & Mean \\
\hline Fodders/grasses & 14.2 & 16.3 & 28.8 & 18.6 & 10.6 & 9.0 & 16.2 \\
\hline Forestry (trees) & 60.1 & 115.4 & 141.1 & 131.7 & 69.9 & 65.3 & 97.2 \\
\hline Agro-forestry & 35.4 & 70.2 & 75.6 & 74.3 & 37.6 & 27.8 & 53.4 \\
\hline Agriculture & 3.9 & 9.8 & 24.3 & 22.7 & 3.7 & 3.1 & 11.2 \\
\hline Agri-horti-silvi-pastoral & 20.1 & 37.4 & 36.0 & 36.5 & 18.2 & 11.6 & 26.6 \\
\hline Horticulture & 65.0 & 101.4 & 124.8 & 80.2 & 70.5 & 51.7 & 82.2 \\
\hline Shifting cultivation & 2950.0 & 4580.0 & 4499.7 & 3610.0 & 3419.1 & 2669.4 & 3621.3 \\
\hline
\end{tabular}

-situ in new land use systems compared to below $60 \%$ in the shifting cultivation. More in-situ retention of rainwater helped in the availability of adequate moisture from the soil to the succeeding crops when the rainy season receded. The sediment yield varied according to the rainfall received during a particular year and the nature of vegetation in a particular land use.

It was interesting to note that while in shifting cultivation $34.1 \%$ of rain water escaped as runoff, it varied from $0.9 \%$ to $7.1 \%$ in the new land use systems. Maximum of $99.1 \%$ of rain water was retained in livestock based land use system, followed by agriculture $(99.1 \%)$. It was reported earlier also that more than $95 \%$ of rain-water can be retained in-situ by following these land use systems (Anonymous 2000). There was significant reduction as well as delay in runoff generation from newly introduced land use systems compared to shifting cultivation. As such there was considerable reduction in the sediment yield. One of the characteristic values in rainfall-runoff modelling is the retention of the system or lag time, which is defined as the time elapsed between the centroids of effective rainfall and the direct runoff hydrograph (Banasik et al. 2005; Banasik et al. 2008). They analyzed the data from small agricultural watersheds to investigate the relationship between instaneous unit hydrograph and instaneous unit sedimentgraph. Annual soil loss due to erosion was considerably higher than the permissible limit (1000 t $\mathrm{km}^{-2}$ ) in the shifting cultivation whereas it was significantly low in the new land use systems. The soil loss was very low in newly tried land use systems due to reduced runoff because of proper vegetation cover and water and soil conservation measures undertaken. These land use systems could be adopted to replace shifting cultivation in the region depending on topography, slope and nearness to the market. The livestock based land use system can be adopted where there is demand for milk or if there is a market for disposal of the animal produce. Similar is the case with the agri-horti-silvipastoral land use system which has horticultural crops as its component.

With new sustainable and eco-friendly land use systems in place, the farmers have an alternative to leave shifting cultivation and go for settled cultivation. This would also help in reducing runoff and soil loss and, improved environmen- 
tal conditions could be assured. In the present study, the runoff water from the land use systems is collected in a pond down the slope and used for irrigation during winter as well as for rearing of fish.

\section{CONCLUSIONS}

The results of the study undertaken showed that the introduction of new land use systems, with suitable water and soil conservation measures, significantly reduced runoff from the watersheds on hill slopes and helped in more in-situ retention of rainwater, thereby reducing the soil and nutrient erosion and silting of river channels, consequently reducing the flood events in the region as well as improving the environment quality. Different land use systems also improved the soil quality with continuous recommended cropping patterns and other measures. The practice of shifting cultivation in northeastern region of India has become uneconomical with increase in demographic pressure and reduction in the shifting cycle period. The practice needs to be replaced with sustainable, socially acceptable and eco-friendly land use systems. Proper policy framework for planning, development and management of land and water resources in the region can be devised, taking advantage of the advances made in water science and technology as well as from positive and negative experiences of the developed countries.

\section{REFERENCES}

ANONYMOUS, 2000: Basic Statistics of the Northeastern Region. North Eastern Council, Shillong, Meghalaya, India.
BANASIK K., MADEYSKI M., MITCHEL J.K., MORI K., 2005: An investigation of lag times for rainfall-runoff-sediment yield events in small river basin. Hydrologic Science Journal, 50(5), 857-866.

BANASIK K., MITCHELL J.K., 2008: Conceptual model of sedimentograph from flood events in a small agricultural watershed. Annals of Warsaw University of Life Sciences, Land Reclam. 39: 49-57.

EL BASSAM N., 1997: Fundamentals of sustainability in agricultural production systems and global food security. In: Sustainable Agriculture for Food, Energy and Industry, (ed. by N. El Bassam, R.K. Behl, B. Prochnow), 1-12, James and James (Publishers, London, U.K.

IFPRI, 1995: A 2020 vision for food, agriculture and the environment. The vision, Challenge and Recommended Action. International Food Policy Research Institute, pp. 50.

JACKSON M.L., 1973: Soil Chemical Analysis. Parentice Hall of India, New Delhi, India

SHARMA U.C., 1998: Water Management by the tribes of northeastern region: The traditional wisdom and future strategies. Fertilizer News: 43, 43-49.

SHARMA U.C., 1999: Food Security in the northeast: new paradigms. In: Persrpective for Planning and Development in North Eastern India (ed. by R.C. Sundariyal, Uma Shankar and T.C. Upreti), 197-212, G.B. Pant Institute of Himalayan Environmental and Development, Almorah, India.

SHARMA U.C., 2001: Effect of farming system type on in-situ ground water recharge and quality in northeast India. In: Impact of human Activity on Groundwater Dynamics (ed. by $\mathrm{H}$. Gehrels, N.E. Peters, E. Hoehn, K. Jenson, C. Leibundgut, J. Griffioen, B. Webb \& W.J. Zaadnoordijk), IAHS Publ. No 269, 167-169, IAHS Press, Wallingford, U.K.

SHARMAU.C., 2003: Impact of population growth and climate change on the quantity and quality of water resources in the northeast region of India. In: Water Resources System - Hydrological Risks, Management and Development. (ed. by G. Bloschl, S. Franks, M. Kumagia, K. Musiake and D. Rosbjerg), IAHS Publ. No 281, 349-357, IAHS Press, Wallingford, U.K.

SHARMA U.C., PRASAD R.N., 1995: Socio-economic aspects of acid sooil management 
and alternate land use systems for northeastern states of India. In: Plant-Soil Interactions at Low pH. (ed. by R.A., Date; N.J. Grundon.; G.E. Rayment and M.E. Probert ), 689-696, Kluwer Academic Press, The Netherlands.

SHARMA U.C., SHARMA V., 2004: Implications of nutrient and soil transfer with runoff in the northeastern reghion of India. In: Sediment Transfer through the Fluvial System (ed. by V. Golosov, V. Belyaev and D.E. Walling). IAHS Publ. No 288, 488-493, IAHS Press, Wallingford, U.K.

SINGH A., SINGH M.D., 1978: Effect of various stages of shifting cultivation on soil erosion from steep hill slopes. Indian Forester, Vol. 106: pp. 115-121.

WALLING D.E., 2000: Linking land use, erosion and sediment yields in river basins. Hydrobiol., 410, pp. 223-240.

WALLING D.E., 2008: The changing sediment loads of the world's rivers. Annals of Warsaw University of Life Sciences, Land Reclam. 39, 3-20.

Streszczenie: Wplyw aspektów społeczno-ekonomicznych oraz zmian zagospodarowania terenu na dynamike wytwarzania rumowiska $w$ pótnocno-wschodnim regionie Indii. W pracy przedstawiono analizę czynników wpływających na wytwarzanie rumowiska $\mathrm{w}$ północno-wschodnim regionie Indii. Do głównych czynników naturalnych można zaliczyć wysokie opady deszczu (średniorocznie $2450 \mathrm{~mm}$ ) oraz duże nachylenie terenu w zlewniach, dochodzące do 32-53\%. Wśród czynników antropogenicznych jako istotne wskazuje się: duży udział gruntów ornych, duże rozdrobnienie i system własności gospodarstw rolnych, postępujące wylesianie oraz swobodny wypas bydła. Stwierdzono, że w wyniku przekształcenia gruntów ornych na inne użytki rolne wzrośnie retencyjność zlewni, a ilości odpływającego rumowiska zmniejszy się o ok. $90 \%$. W tym celu konieczne są działania o charakterze prawnym, planistycznym, z zakresu gospodarki wodnej i zagospodarowania terenu.

\section{MS. received April 2010}

Authors' addresses:

\section{U.C. Sharma}

Centre for Natural Resources Management

V. P. O. Tarore, district Jammu, 181133, J \& K India

e-mail: ucsharma2@rediffmail.com

\section{Vikas Sharma}

S.K. University of Agricultural Sciences \& Technology

Chatha, Jammu, 180009 J\&K

India 